\title{
Measuring investor relations and financial communication: an empirical test of scales of public relations
}

Medindo relações com investidores e comunicação financeira: teste empírico das escalas de relações públicas

Evaluación de las relaciones con inversionistas y comunicación financiera: prueba empírica de las escalas de relaciones públicas 


\section{Abstract}

Models of public relations became one of the most researched paradigms in public relations. Yet, after their reconceptualization into dimensions, researchers focused on developing models/dimensions virtually disappeared. This study proposes to continue this research by reconceptualizing models/dimensions into the public relations scales. This paper reports the first empirical test of the Scales of Public Relations by applying them to one of PR specializations - investor relations.

\section{KEYWORDS: SCALES OF PUBLIC RELATIONS・DIMENSIONS OF PUBLIC RELATIONS・INVESTOR RELATIONS.}

\section{Resumo}

Os modelos de relações públicas tornaram-se um dos paradigmas mais pesquisados no campo das relações públicas. No entanto, depois que os modelos foram reconceituados em dimensões, os pesquisadores focados no desenvolvimento de modelos/dimensões praticamente desapareceram. Este estudo, entretanto, põe à prova os modelos/dimensões reconceituados: as escalas de relações públicas. Este estudo relata o primeiro teste empírico das escalas de relações públicas, aplicando-as a uma das especializações de relações públicas, as relações com investidores.

\section{PALAVRAS-CHAVE: ESCALAS DE RELAÇÕES PÚBLICAS • DIMENSÕES DE RELAÇÕES PÚBLICAS・RELAÇÕES COM INVESTIDORES.}

\section{Resumen}

Los modelos de relaciones públicas se han convertido en uno de los paradigmas más investigados en el campo de las relaciones públicas. Sin embargo, luego de que los modelos fueron reconceptualizados en dimensiones, los investigadores enfocados en el desarrollo de modelos/dimensiones prácticamente desaparecieron. Este estudio, sin embargo, pone a prueba los modelos/ dimensiones reconceptualizados: Las Escalas de Relaciones Públicas. Este estudio reporta la primera prueba empírica de las Escalas de Relaciones Públicas, aplicándolas a una de las especialidades de las relaciones públicas, las relaciones con inversionistas. 


\section{INTRODUCTION}

M odels of public relations (press-agentry/publicity, public information, two-way asymmetrical, and two-way symmetrical) can be traced back to 1976 publications by J. Grunig, who classified the various public relations tactics into two large groups: synchronic and diachronic. But these models truly earned their place in the body of knowledge within the Excellence project: "Over the last 20 years, a leading body of work has developed around Symmetry/Excellence Theory, which has probably done more to develop public relations theory and scholarship than any other single school of thought" (Botan; Hazleton, 2006, p.6).

While models of public relations became the driving force behind the theory-building efforts in public relations, they also drew their fair share of criticism: "The four models of public relations, and especially the two-way symmetrical model, have been the most controversial and the most debated component of the Excellence theory since our theory book was published" (Grunig; Grunig; Dozier, 2002, p.307). Many critics argued against the very concept of symmetry as a impractical or unrealistic utopia (Dover, 1995; Kunczik, 1994; L'Etang, 1995; Leitch; Neilson, 2001; Pieczka, 1995); others posited that symmetry should not even be considered a normative goal (Creedon, 1993; Holtzhausen, 2000; Lyotard, 1992; Pieczka, 1996; Roper, 2005). Part of this criticism focused on the methodological and measurement issues of the models' development: questionnaire, measurement range, and instrument reliability (Leichty; Springston, 1993; Murphy, 1989; 1991).

Later, the team of scholars behind the models proposed to transition from models to dimensions of public relations (Grunig et al., 2002). After reviewing this transition, Laskin (2009) proposed a new approach to further modify the models and dimensions of public relations (2012). Labeled Public Relation Scales, Laskin's reconceptualization included two original dimensions, underlying the original models, and three additional ones; but this was a purely theoretical concept. This study addresses this shortcoming by applying the Scales to one of the field's specializations - investor relations -, to collect primary empirical data and validate the concept of Scales of public relations.

\section{LITERATURE REVIEW}

Laskin (2012) proposed to develop continuous dimensions of public relations capable of measuring direction of communication and balance of intended effects - foundational dimensions of the original models-, adding new dimensions: organizational roles of public relations professionals, timeframe of public relations professionals, and strategic nature of public relations activities.

\section{Direction of communication scale}

Since early conceptualizations, direction of communication served as an important variable in understanding public relations activities (Grunig, 1984; Grunig; Grunig, 1992), comprising one of the two foundational dimensions of the original models (Grunig et al., 2002). Two-way communication means that public relations professionals are both talking and listening: "communication flows both to and from publics" (Grunig; Hunt, 1984, p. 23). Two of the earlier models - press-agentry/ publicity and public information - were based on the one-way information flow, from the organization to the public, while the two later models - two-way asymmetrical and two-way symmetrical - were based on the two-way flow, per their names.

When analyzing the transition from models to dimensions, however, Laskin (2012) notes that the latter failed to be conceptualized in a dichotomous manner that would provide variance for measurability. Rather, the dimension was conceptualized as ranging 
from a one-way communication, on the one end, to a two-way communication, on the other; in other words, considering communications established from the organization to the publics on both poles of the dimensions, but paired with reverse communications (publics-organization) in the latter.

Attempting to create better dimensions, Grunig et al. (2002) re-evaluated the models and dropped the direction of communication as a continuous dimension, and proposed, instead, two separate dimensions measured independently: one-way communication dimension and two-way communication dimension. But these are not continuous dimensions between two opposing poles, only a typology. Communications are characterized as having or not having a certain type of activity, in the same way that the models were in fact clusters of specific activities.

In response, Laskin (2012) proposed a dimension scale with organization-to-public communications at one pole, and public-toorganization communications at the opposite pole. Two-way communication, then, becomes dual-directional communicationgraphically positioned near the middle on the Direction of Communication Scale between two opposite poles, representing a situation in which communication flows both ways. Such a scale represents a continuum, and positioning various public relations programs or organization on this continuum would allow us to compare and contrast relative levels of two-way communication (Figure 1).

Figure 1: Direction of Communication Scale

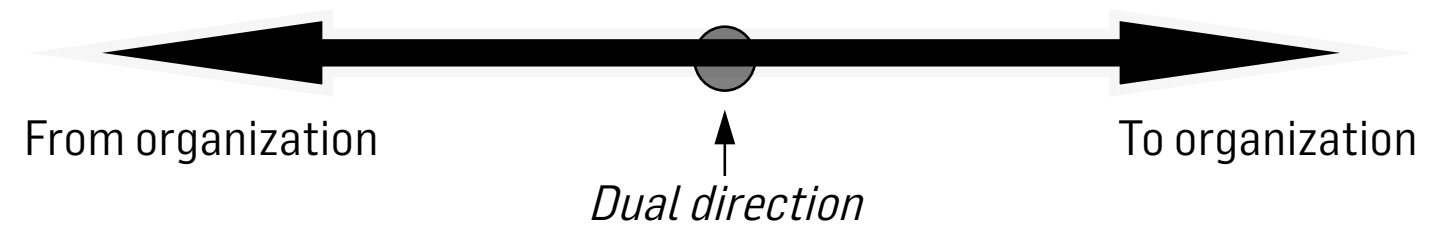

Source: Elaborated by the author.

\section{Intended beneficiary scale}

The second dimension underlying the models is the balance of intended effects - symmetry versus asymmetry. But when this dichotomy was later re-created into dimensions, Laskin (2012) notes, it suffered from the same problem as the direction of communication dimension: the opposite poles of the proposed dimension were not really dichotomous to each other. The original concept (Grunig et al., 2002) had asymmetrical intent as one pole of the dimension, where the organization intends to benefit only itself, and symmetrical intent at the opposite pole, where the organization intends to benefit itself and its publics. Conceptualized as a non-continuum, the dimension had no logical progression between the opposing poles; thus, as in the direction of communication, the continuous dimensions subsequently disappeared from the proposal after being introduced.

Moreover, the two-way asymmetrical model was difficult to measure for the model relied on variables that measure research in public relations. J. Grunig (1984) posited that social science research is used by organizations to asymmetrically persuade the public and thus proposed to measure asymmetrical intent through research. In reality, however, professionals do not divide research into asymmetric and symmetric. When recreated as a dimension, the same questions about research became the basis for the asymmetrical dimension. This rendered the proposed dimension meaningless: it seemed to suggest that conducting research is an activity opposed to conducting symmetrical communications - a situation not reflected in public relations practice or theory. Thus, it was important to move away from research as a qualifier for this dimension.

As a result, Laskin (2012) proposed to reconceptualize the dimension of intended effects as the Intended Beneficiary Scale, with the organization's intended benefit at one pole, and the public's intended benefit at the opposite pole. The resulting continuum puts the symmetrical model - also called dual-motives or mutually-beneficial relationships - in between the 
opposing poles (Figure 2). Again, different public relations activities could be compared with each other for a relative share of activities aimed at internal or external beneficiaries.

Figure 2. Intended Beneficiary Scale

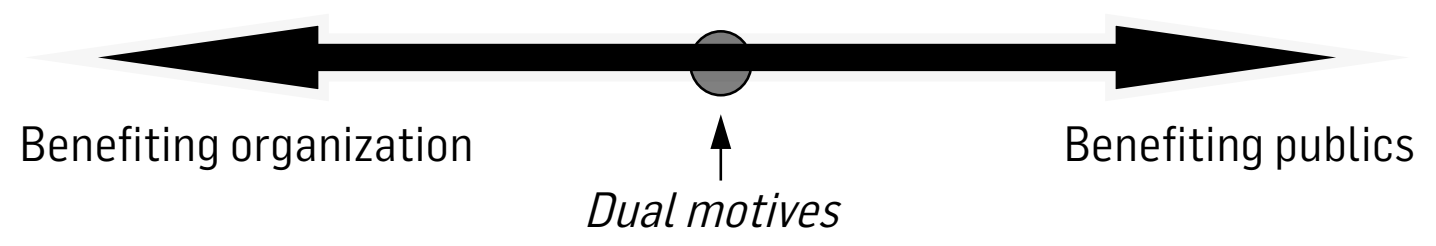

Source: Elaborated by the author.

\section{Strategic nature scale}

Since conducting research is an important predictor of excellence in public relations, once removed from the Intended Beneficiary Scale, the research measurements were allocated into the Strategic Nature Scale. Indeed, the strategic intent behind public relations and whether such activities are proactive or reactive in nature are important considerations in analyzing a public relations practice. One of the key determinants of excellent public relations is being able "to recognize problems before they happen" (Heath; Coombs, 2006, p.166). Excellence project's models include several questions about research in public relations, measuring several variables related to its proactive nature. Despite their importance, however, these variables were not commonly organized into a standalone measure.

Laskin (2012) proposed isolating research and planning on a special continuum - the Strategic Nature Scale -, having proactive research-based activities at one pole, and reactive activities at the opposite pole (Figure 3). Public relations programs are likely to engage in both proactive and reactive practices and therefore can be positioned along the continuum. As with the previous scales, one should be able to measure the relative weights of each type of activity and, as a result, compare different public relations programs with each other.

Figure 3. Strategic Nature Scale

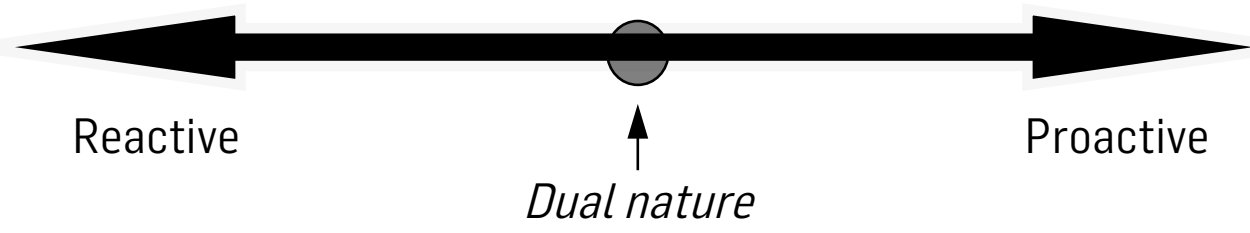

Source: Elaborated by the author.

\section{Role scale}

The Excellence project concluded that the best indicator of excellent public relations is one's ability to play the role of manager: "Of all the measures made of participating organizations, one set does the best job of measuring communication excellence. That set measures knowledge of those individuals in the communication department to play the role of communication manager" (Dozier; Grunig; Grunig, 1995, p.23). Yet, the previous models and dimensions of public relations failed to consider this variable.

Dozier and Broom (2006) define the concept of organizational role as "abstractions, conceptual maps that summarize the most salient features of day-to-day behaviors of organizational members" (p.137), initially proposing four separate roles: technician, expert prescriber, process facilitator, and communication facilitator. Much of the research into organizational roles in public relations concludes, however, that three of these roles (expert prescriber, process facilitator, and communication facilitator) can be combined into one: communication manager (Broom, 1982; Dozier, 1983; 1984). Dozier and Broom (2006) 
explain that role analysis using the manager-technician dichotomy "has proved very stable over numerous studies of different practitioner populations" (p.141). The importance of organizational roles in analyzing and understanding public relations practice is underlined by this aspect being one of the most studied areas in public relations academic research (Pasadeos; Renfo; Hanily, 1999). Dozier and Broom (2006) conclude that public relations role is a concept central to "a wide range of professional and organizational antecedents and outcomes" (2006, p.137).

As a result, Laskin $(2009 ; 2012)$ incorporated the organizational role in his proposal with the Role Scale. This combines the models/dimensions with the body of knowledge on organizational role - two fields of research often treated independently; despite being considered as interrelated concepts by the Excellence project authors. In Laskin's Role Scale, one pole represents technical activities and the opposite pole represents managerial activities (Figure 4). Professionals are expected to conduct a mix of both types of activities, and will therefore be located somewhere on the continuum, with different relative weights of each type of activity in their role.

Figure 4. Enacted role scale

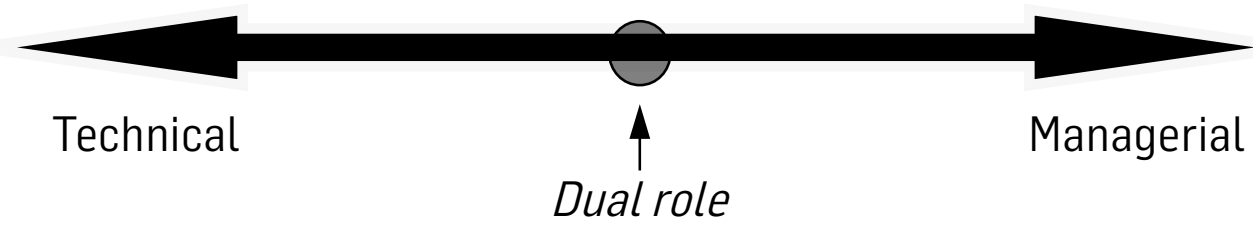

Source: Elaborated by the author.

\section{Timeframe Scale}

Finally, Laskin (2009; 2012) proposed the use of the Timeframe Scale as to integrate the models/dimensions and organizational roles with the relationship-building measures (Ferguson, 1984; Ledingham, 2003). Such scale, however, does not measure the relationship itself, its type or outcome; rather, it focuses, as all other scales, on public relations practice. It thus measures the long-term versus short-term relationship-building focus of public relations professionals, departments, or programs.

Similar to the previous scales, this is a continuous measurement, where one pole represents long-term public relations practices, while the opposite pole represents short-term practices (Figure 5). As such, public relation professionals are likely to combine both approaches, positioning themselves somewhere along the continuum, and can be compared between each other based on their relative share of long- and short-term practices.

Figure 5. Timeframe scale

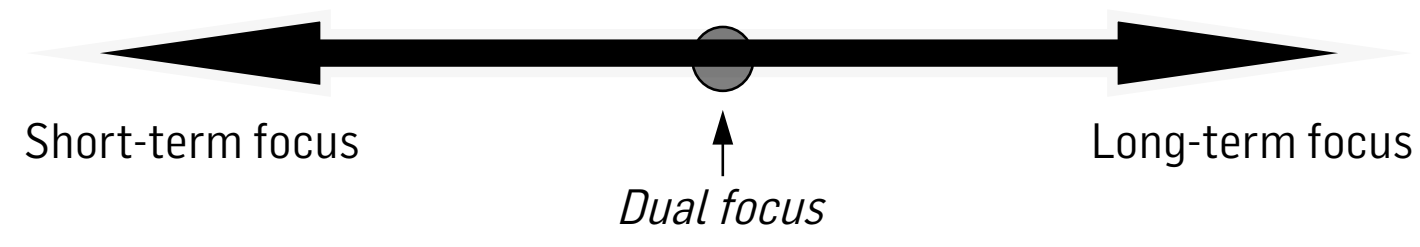

Source: Elaborated by the author.

\section{Measurement}

According to Laskin (2012), each of the proposed Scales of public relations measures a key aspect of public relations practice on a continuum between two opposing poles, thus placing each measurement unit on this continuum and enabling comparisons between the units. The Direction of Communication scale, for example, assesses the direction of the communication flow from the organization to its public; from the public to the organization -, asking questions about both types of communications. 
The collected data are then plotted on the continuum, where organization-public communications and public-organization communications represent its opposing poles. To this end, the questionnaire items about communications from organizations are combined and coded negatively, while the items about communications from the public are combined and coded positively.

If measured on a scale from 0 to 10 , for example, the scale will be as depicted in Figure 6 . As one of the poles is coded negatively and the other positively, results from -2 to +2 indicate a perfect balance and dual direction of communication $-i$.e., public relations professionals focus on a two-way communication between organization and public. Results from +2 to +6 reveal a preference for communications from the public, while results from +6 to +10 represent the dominance of publicorganization communications in the public relations practices. Such practices will be primarily focused on listening rather than informing. Results from -10 to -6 , in turn, show the organization's almost exclusive focus on spreading information to the public with disregard to listening. Results from -6 to -2 , on the other hand, indicate that communication flows from the organization prevail in comparison with those directed to the organization.

Figure 6. Proposed measurement of direction of communication scale (Positive/Negative)

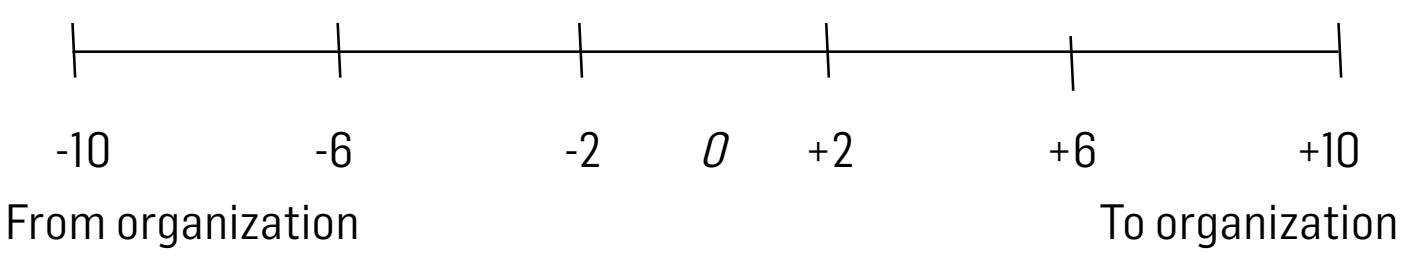

\section{Dual direction}

Source: Elaborated by the author.

From a methodological standpoint, coding opposite items on the same scale as positive and negative is beneficial; but from a conceptual standpoint, it is better to avoid such presentation. Coding items as positive or negative can introduce unnecessary stigma: negatively-coded items can be perceived as inferior to positively-coded items. Critics of the original models and dimensions of public relations claimed that the models failed precisely because they labeled many practices as inferior, arguing for a utopian ideal (Kunczik, 1994; Pieczka, 1995; L'Etang, 1995). Thus, the newly proposed reconceptualization must avoid this issue.

Also unreasonable is to consider communication flows from the organization as inferior to feedback from the public, or vice versa. The same is true for any other scale. Excellent public relations should have interests of both organizations and public in mind, should be capable of exercising both managerial and technical roles, be able to plan proactive activities but also capable of nimble action in response to unexpected issues, and act according to short- and long-term timeframes. Thus, although the items are coded as positive or negative for calculation purposes, the final report should avoid such coding, using instead letters to indicate the different poles of the scales (Figure 7).

Figure 7. Proposed measurement of direction of communication scale

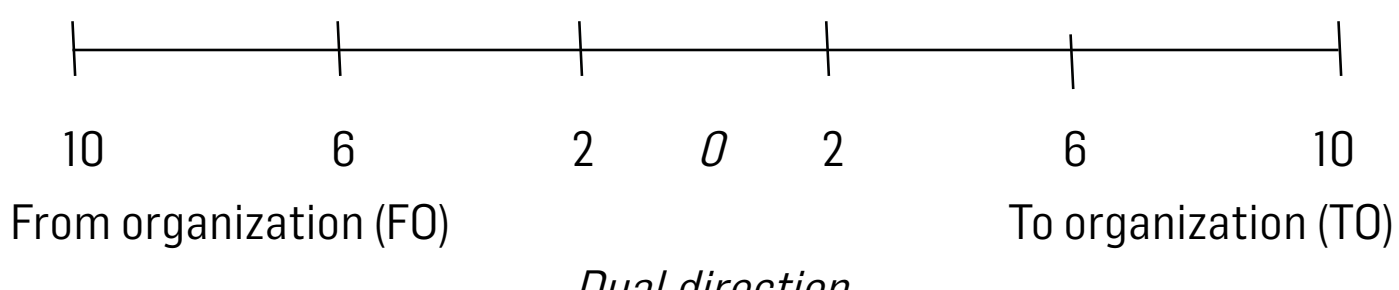

Source: Elaborated by the author.

When measured together, these scales can present a comprehensive picture of public relations practices. Thus, the study proposes the following research question: What is the general description of investor relations practice based on the Scales of Public Relations? 


\section{METHOD}

This study has the quantitative survey as its main methodology, one of the leading methods of inquiry in social sciences. Wimmer and Dominick (2003) explain that "decision makers in businesses, consumer and activist groups, politics, and the media use survey results as part of their daily routine" (p.167). Such a wide applicability results from the following advantages of survey research: realistic settings, large amount of data, no geographic constraints, and reasonable costs. The study also used a qualitative pre-test to validate the survey questionnaire and gain additional feedback from the professionals.

The study population comprised investor relations officers (IROs) of publicly traded corporations. Investor relations is one of the PR specializations aimed at financial audiences, such as investors and financial analysts (Laskin, 2011; 2014; 2018). In fact, the Excellence project reported that different specializations practice different models of public relations even within the same organization. Media and community relations, for example, were more likely to practice press agentry, while customer relations practiced two-way asymmetrical public relations. Out of all these specializations, however, investor relations was the only one found to predominately practice the two-way symmetrical model (Grunig et al., 2002; Kelly et al., 2010; Laskin, 2016).

Our sample was drawn from the professional organization of investor relations professionals - the National Investor Relations Institute. Founded in 1969, NIRI is the largest professional organization of investor relations consultants, with about 3,000 members. Since our goal was to extrapolate the research findings to the overall population under study, we obtained a representative sample using probability sampling. By setting a $5 \%$ confidence interval at $99 \%$ confidence level, the study required a sample size of about 560 respondents. Using a random number function, we selected 560 investor relations officers from the total NIRI membership.

Comprising 20 items, the questionnaire evaluated the IROs activities via five dichotomous scales, whose specific items were created based on the literature on models/dimensions of public relations (Grunig, 1984; Grunig et al., 2002; Huang, 2007; Laskin, 2009; 2012; Sha, 2007), roles of public relations professionals (Dozier et al., 1995; Dozier; Broom, 2006), relationship management (Ferguson, 1984; Hon; Grunig, 1999), and investor relations (Laskin, 2014; 2016; 2018). All items were modified to match the focus of the study.

Direction of communication was assessed by four questions: the first two measure the flow of information from the company to the investment community; the other two measure the flow of information from the investment community to the company. Based on the literature (Grunig et al., 2002; Laskin, 2009; 2011) the study proposed the following hypothesis:

$\mathrm{H1}$ : Investor relations is characterized by two-way communication.

Intended beneficiary of communication was measured by four questions: two measuring the company as intended beneficiary, and the two measuring the public as intended beneficiary. Based on previous research (Grunig et al., 2002; Laskin, 2009; 2011) the study proposed the following hypothesis:

H2: Investor relations is characterized by dual motives.

Roles of investor relations officers was assessed by four questions, based on Broom and Dozier's research (Broom, 1982; Broom; Dozier, 1986; Dozier; Broom, 1995): the first two measure the managerial role and the last two measure the technical role. Based on previous research (Grunig et al., 2002; Dozier; Broom, 1995; Laskin, 2009; 2010) the study proposes the following hypothesis:

H3: Investor relations is characterized mainly by exercising a managerial role. 
Based on Grunig et al.'s (2002) research on public relations and Dozier and Broom's (1995) study on the role of process facilitator, we created four questions to measure the strategic nature of communications: two measuring research and strategic planning, and two items measuring reactive communications to the public's actions. Based on the literature (Grunig et al., 2002; Laskin, 2009; 2010) the study proposed the following hypothesis:

H4: Investor relations is characterized by strategic proactive communications.

Finally, to measure the time focus of investor relations, the study borrowed from Hon and Grunig's (1989) research on long- and short-term practices, and developed new items to measure long-versus short-term investor relations practice specifically. Thus, the first two questions measure long-term focus, and the last two assess short-term focus. Based on previous research (L. Grunig et al., 2002; Laskin, 2010; 2011) the study proposed the following hypothesis:

H5: Investor relations is characterized by using primarily a long-term focus on relationship building.

Before applying the questionnaire, the research conducted a qualitative pre-test to analyze the items and discuss their wording and possible improvements. In-depth interviews were conducted with a purposive sample of 10 respondents who were knowledgeable and experienced in investor relations. Each survey item was discussed in detail, with the interviewer allowing deviations from the survey questions, if necessary.

The final instrument was posted on the internet and an invitation to participate was sent by email. We took several measures to increase the response rate, including offering the respondents access to the final report and sending a reminder two weeks after the first email. Of the 560 e-mails, 22 returned as "failure sending." After additional effort to locate the correct contact information for those IROs, 13 of these e-mails were delivered to the recipients and nine remained undeliverable. As a result, we reduced the study sample to 551 investor relations officers. The survey resulted in 182 completed responses for a $33 \%$ response rate.

\section{RESULTS}

\section{Research question 1: Description of investor relations practice}

The questionnaire asked respondents to rate 20 statements on a 10-point scale, where 0 was "Strongly Disagree" and 10 "Strongly Agree", based on the degree to which the statement described their work, and their mean scores were later calculated. Table 1 presents the 20 statements and their mean scores, from highest to lowest mean.

Table 1. Mean scores of individual items of investor relations activities

\begin{tabular}{|l|c|c|c|c|c|}
\hline \multicolumn{1}{|c|}{ Activities } & $M$ & $\sigma$ & $N$ & SES & SEK \\
\hline I explain my company to the investment community & 9.73 & .93 & 182 & .180 & .358 \\
\hline $\begin{array}{l}\text { I answer requests from shareholders/investors, } \\
\text { analysts, media, or senior management }\end{array}$ & 9.40 & 1.38 & 182 & .180 & .358 \\
\hline I disclose information about my company & 9.37 & 1.62 & 181 & .181 & .359 \\
\hline $\begin{array}{l}\text { I deliver information from the investment } \\
\text { community to senior management }\end{array}$ & 9.35 & 1.36 & 182 & .180 & .358 \\
\hline
\end{tabular}


Table 1. Continuation

\begin{tabular}{|c|c|c|c|c|c|}
\hline Activities & M & $\sigma$ & N & SES & SEK \\
\hline $\begin{array}{l}\text { I develop long-term relationships between } \\
\text { investors/analysts and my company }\end{array}$ & 9.25 & 1.42 & 182 & .180 & .358 \\
\hline $\begin{array}{l}\text { I keep senior management knowledgeable } \\
\text { about our shareholders and analysts }\end{array}$ & 9.17 & 1.43 & 182 & .180 & .358 \\
\hline $\begin{array}{l}\text { I keep up with the current stock price } \\
\text { and volume fluctuations }\end{array}$ & 8.93 & 1.84 & 181 & .181 & .359 \\
\hline $\begin{array}{l}\text { I write and edit texts and prepare } \\
\text { presentations/speeches }\end{array}$ & 8.91 & 1.78 & 182 & .180 & .358 \\
\hline $\begin{array}{l}\text { I am responsible for quickly finding } \\
\text { information for somebody who needs it }\end{array}$ & 8.81 & 1.64 & 182 & .180 & .358 \\
\hline $\begin{array}{l}\text { I develop goals and objectives for my } \\
\text { company's investor relations program }\end{array}$ & 8.66 & 2.29 & 182 & .180 & .358 \\
\hline $\begin{array}{l}\text { I manage all aspects of my company's } \\
\text { investor relations program }\end{array}$ & 8.51 & 2.72 & 182 & .180 & .358 \\
\hline I cultivate long-term focus in stock ownership & 8.33 & 2.01 & 181 & .181 & .359 \\
\hline $\begin{array}{l}\text { I handle technical aspects of my company's } \\
\text { investor relations program }\end{array}$ & 8.26 & 2.22 & 182 & .180 & .358 \\
\hline $\begin{array}{l}\text { I make sure that management considers } \\
\text { investors' opinions in its decision making }\end{array}$ & 8.03 & 2.12 & 182 & .180 & .358 \\
\hline $\begin{array}{l}\text { I protect the reputation of senior management } \\
\text { in the eyes of the investment community }\end{array}$ & 8.00 & 2.17 & 182 & .180 & .358 \\
\hline $\begin{array}{l}\text { I defend my company's actions in the } \\
\text { eyes of the investment community }\end{array}$ & 7.84 & 2.20 & 182 & .180 & .358 \\
\hline $\begin{array}{l}\text { I provide earning's guidance and } \\
\text { current financial results }\end{array}$ & 7.61 & 3.20 & 182 & .180 & .358 \\
\hline I conduct research to anticipate relevant issues & 7.48 & 2.45 & 181 & .181 & .359 \\
\hline $\begin{array}{l}\text { I make sure that management acts in } \\
\text { the best interests of shareholders }\end{array}$ & 7.12 & 2.50 & 182 & .180 & .358 \\
\hline $\begin{array}{l}\text { I rely on planning and diagnosing needs/ } \\
\text { opportunities to do my work }\end{array}$ & 6.76 & 2.50 & 181 & .181 & .359 \\
\hline
\end{tabular}

Source: Elaborated by the author.

According to the results, investor relations officers point to "explaining" as the best descriptor of their work. The highest rated item was "I explain my company to the investment community" (M=9.73; $N=182)$, followed by "I answer requests from shareholders/ investors, analysts, media, or senior management" $(M=9.40 ; N=182)$. Other items that scored high (above 9 on a 10-point scale) were: "I disclose information about my company" $(M=9.37 ; N=181) ;$ "I deliver information from the investment community to senior management" $(M=9.35 ; N=182) ;$ "I develop long-term relationships between investors/analysts and my company" $(M=9.25 ; N=182)$; and "I keep senior management knowledgeable about our shareholders and analysts" $(M=9.17 ; N=182)$.

These 20 statements measure five Scales of Public Relations practice: direction of communication, intended beneficiary, enacted role, strategic nature, and timeframe of investor relations. 


\section{Hypothesis 1: Investor relations is characterized by two-way communication}

The direction of communication scale measured whether investor relations communication is directed from the company to investors or vice versa. Our findings suggest that investor relations practice is best described as having a dual direction, i.e., employing two-way communication. IROs described their work as communicating both from the company to investors and from investors to the company. Its mean score was close to the midpoint in the direction of communication continuum $(M=0.59 ; N=181)$. Although the mean for communication from the company was higher than the mean for communication to the company, the difference between them was not statistically significant $(t=2.79 ; p>.001)$, thus corroborating Hypothesis 1.

Regarding the reliability of the scale, the study considered $\alpha=.60$ or higher as a satisfactory reliability, per Bowers and Courtright (1984) recommendations. The analysis found $\alpha=.70$, thus sufficiently reliable.

Table 2. Direction of communication scale

\begin{tabular}{|c|c|c|c|c|c|}
\hline Activities & $M$ & $\sigma$ & $N$ & SES & SEK \\
\hline I disclose information about my company (FO) & 9.37 & 1.62 & 181 & .181 & .359 \\
\hline $\begin{array}{l}\text { I explain my company to the } \\
\text { investment community (FO) }\end{array}$ & 9.73 & .93 & 182 & .180 & .358 \\
\hline $\begin{array}{l}\text { I deliver information from the investment } \\
\text { community to senior management (TO) }\end{array}$ & 9.35 & 1.36 & 182 & .180 & .358 \\
\hline $\begin{array}{l}\text { I keep senior management knowledgeable } \\
\text { about our shareholders and analysts (TO) }\end{array}$ & 9.17 & 1.43 & 182 & .180 & .358 \\
\hline Direction of communication scale (FO - TO) & $.59 \mathrm{FC}$ & 2.82 & 181 & .181 & .359 \\
\hline Cronbach's $\alpha$ for reliability & .70 & & 181 & & \\
\hline
\end{tabular}

Source: Elaborated by the author.

Figure 8. Direction of communication scale

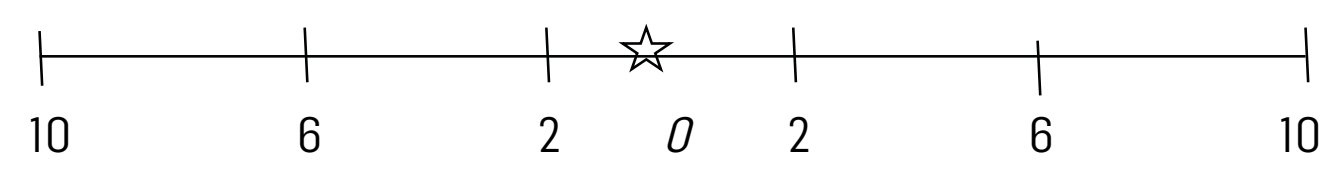

From organization (FO) To organization (TO)

Dual direction

Source: Elaborated by the author.

\section{Hypothesis 2: Investor relations is characterized by balanced intended effects (dual motives)}

The intended beneficiary scale measured the extent to which investor relations work advanced the company's interests or those of its shareholders. Our findings suggest that investor relations practice is best described as having dual motives. IROs described their work as influencing the investment community for the interests of management, and vice versa. The mean score of the intended beneficiary continuum was close to the midpoint $(M=0.68 ; N=182$ ), with management as the sole beneficiary of investor relations scoring slightly higher than investment community as the sole beneficiary. The difference between means, however, was not statistically significant ( $t=2.00 ; p>.001)$, thus supporting Hypothesis 2 . Regarding the reliability of the intended beneficiary scale, our analysis found it sufficiently reliable $(\alpha=.73)$. 
Table 3. Intended beneficiary scale

\begin{tabular}{|c|c|c|c|c|c|}
\hline Activities & M & $\sigma$ & $N$ & SES & SEK \\
\hline $\begin{array}{l}\text { I protect the reputation of senior management } \\
\text { in the eyes of the investment community (BM) }\end{array}$ & 8.00 & 2.17 & 182 & .180 & .358 \\
\hline $\begin{array}{l}\text { I defend my company's actions in the eyes } \\
\text { of the investment community (BM) }\end{array}$ & 7.84 & 2.20 & 182 & .180 & .358 \\
\hline $\begin{array}{l}\text { I make sure that management acts in the } \\
\text { best interests of shareholders (BI) }\end{array}$ & 7.12 & 2.50 & 182 & .180 & .358 \\
\hline $\begin{array}{l}\text { I make sure that management considers } \\
\text { investors' opinions in its decision making (BI) }\end{array}$ & 8.03 & 2.12 & 182 & .180 & .358 \\
\hline Intended beneficiary scale (BM - BI) & $.68 \mathrm{BM}$ & 4.59 & 182 & .180 & .358 \\
\hline Cronbach's $\alpha$ for reliability & .73 & & 182 & & \\
\hline
\end{tabular}

Source: Elaborated by the author.

Figure 9. Intended Beneficiary Scale

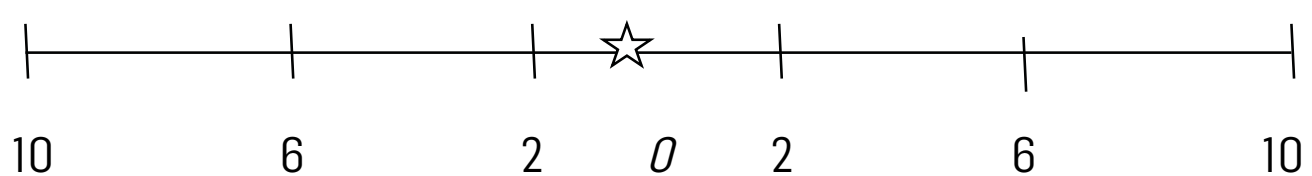

$\begin{array}{lllllll}10 & 6 & 2 & 0 & 2 & 6 & 10\end{array}$

Benefiting management (BM) Benefiting investors (BI)

Dual motive

Source: Elaborated by the author.

\section{Hypothesis 3: Investor relations is characterized by exercising a managerial role}

The role scale has the technical role and the managerial role as its two opposing poles, since, in their daily work, IROs may take on both managerial and technical (writing and editing) tasks. The continuum combines four questions - two measuring managerial activities and two measuring technical activities - to assess the proposed hypothesis that investor relations work is primarily managerial, with management tasks rated higher than technical ones.

Our findings suggest that investor relations practice is best described as having a dual role, being both managerial and technical. Investor relations officers rated the managerial aspects of their job as high as the technical aspects. The mean score was exactly at the midpoint of the continuum ( $M=.00 ; N=182)$, thus refuting Hypothesis 3 . The reliability of the role scale found was sufficient $(\alpha=.61)$.

Table 4. Enacted role scale

\begin{tabular}{|l|c|c|c|c|c|}
\hline \multicolumn{1}{|c|}{ Activities } & $M$ & $\sigma$ & $N$ & SES & SEK \\
\hline $\begin{array}{l}\text { I manage all aspects of my company's } \\
\text { investor relations program (MR) }\end{array}$ & 8.51 & 2.72 & 182 & .180 & .358 \\
\hline $\begin{array}{l}\text { I develop goals and objectives for my } \\
\text { company's investor relations program (MR) }\end{array}$ & 8.66 & 2.29 & 182 & .180 & .358 \\
\hline $\begin{array}{l}\text { I handle technical aspects of my company's } \\
\text { investor relations program (TR) }\end{array}$ & 8.26 & 2.22 & 182 & .180 & .358 \\
\hline
\end{tabular}

Continues... 
Table 4. Continuation

\begin{tabular}{|l|c|c|c|c|c|}
\hline \multicolumn{1}{|c|}{ Activities } & $M$ & $\sigma$ & $N$ & SES & SEK \\
\hline $\begin{array}{l}\text { I write and edit texts and prepare } \\
\text { presentations/speeches (TR) }\end{array}$ & 8.91 & 1.78 & 182 & .180 & .358 \\
\hline Enacted role scale (MR - TR) & .00 & 4.73 & 182 & .180 & .358 \\
\hline Cronbach's $\alpha$ for reliability & .61 & & 182 & & \\
\hline
\end{tabular}

Source: Elaborated by the author.

Figure 10. Enacted role scales

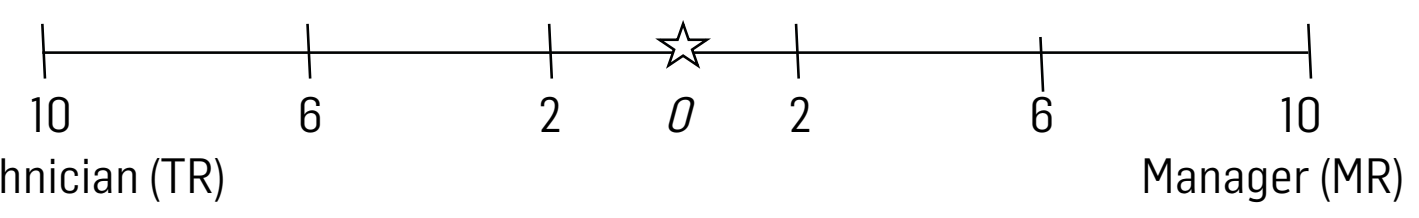

Dual role

Source: Elaborated by the author.

\section{Hypothesis 4. Investor relations is characterized by proactive communication}

The strategic nature of investor relations professionals scale measures the proactive and reactive tasks involved in daily investor relations operations: the continuum has proactive activities based on planning and anticipating relevant issues at one pole, and passive and reactive activities in response to requests from financial audiences at the other pole. The study proposed, then, that investor relations officers would perceive their work as being primarily proactive.

Our findings suggest that investor relations practice is best described as being reactive in nature. IROs rated proactive work, such as relying on planning and diagnosis and conducting research to anticipate relevant issues significantly lower than reactive work, such as responding to requests from various constituencies. The mean score leaned towards the reactive side of the nature of work continuum $(M=3.98 ; N=180)$, resulting in a statistically significant difference between reactive and proactive communication means $(t=3.40 ; p \leq .001)$ and thus refuting Hypothesis 4 . The reliability of the strategic nature of work scale was sufficient $(\alpha=.72)$.

Table 5. Strategic nature scale

\begin{tabular}{|c|c|c|c|c|c|}
\hline Activities & $M$ & $\sigma$ & $N$ & SES & SEK \\
\hline $\begin{array}{l}\text { I conduct research to anticipate } \\
\text { relevant issues (PA) }\end{array}$ & 7.48 & 2.45 & 181 & .181 & .359 \\
\hline $\begin{array}{l}\text { I rely on planning and diagnosing needs/ } \\
\text { opportunities to do my work (PA) }\end{array}$ & 6.76 & 2.50 & 181 & .181 & .359 \\
\hline $\begin{array}{l}\text { I answer requests from shareholders/investors, } \\
\text { analysts, media, or senior management (RA) }\end{array}$ & 9.40 & 1.38 & 182 & .180 & .358 \\
\hline $\begin{array}{l}\text { I am responsible for quickly finding } \\
\text { information for somebody who needs it (RA) }\end{array}$ & 8.81 & 1.64 & 182 & .180 & .358 \\
\hline Strategic nature scale (PA - RA) & $3.98 \mathrm{RA}$ & 4.19 & 181 & .181 & .359 \\
\hline Cronbach's $\alpha$ for reliability & .72 & & 181 & & \\
\hline
\end{tabular}

Source: Elaborated by the author. 
Figure 11. Strategic nature scale

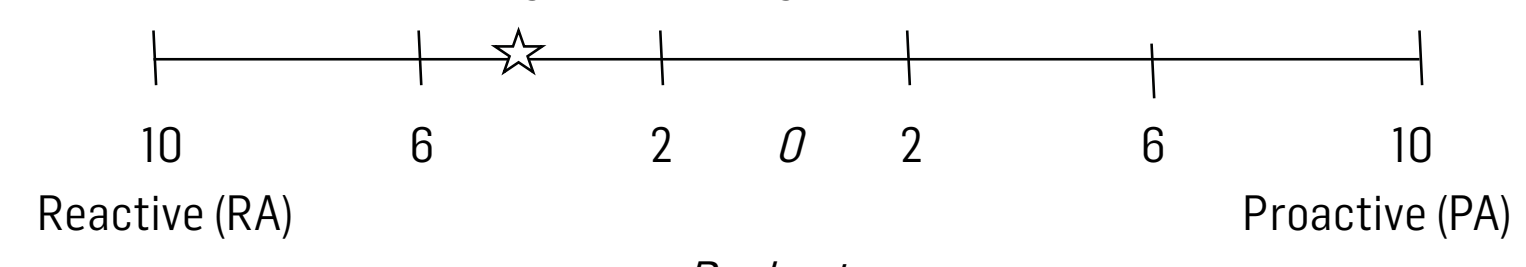

Dual nature

Source: Elaborated by the author.

\section{Hypothesis 5: Investor relations is characterized by long-term focus on relationship building}

The timeframe scale measures the perceived importance of relationship-building activities within investor relations practices, having the short-term focus at one pole of its continuum and the long-term focus of investor relations professionals at the other pole. Thus, the proposed hypothesis was that investor relations officers would perceive their work as being long-term oriented.

Our findings suggest that investor relations practice is best described as having a dual focus on both long-and short-term objectives, with the resulting mean score placed in the middle of the focus continuum $(M=1.04 ; N=181)$. Although the mean for long-term objectives was significantly higher than that for short-term objectives, resulting in a statistically significant difference between them $(t=3.40 ; p \leq .001)$, this difference is not conceptually significant - results from -2 to +2 are considered as dual focus. Thus, Hypothesis 5 is inconclusive. The reliability of the nature of work scale was sufficient $(\alpha=.70)$.

Table 6. Timeframe scale

\begin{tabular}{|c|c|c|c|c|c|}
\hline Activities & M & $\sigma$ & N & SES & SEK \\
\hline $\begin{array}{l}\text { I develop long-term relationships between } \\
\text { investors/analysts and my company (LT) }\end{array}$ & 9.25 & 1.42 & 182 & .180 & .358 \\
\hline I cultivate long-term focus in stock ownership (LT) & 8.33 & 2.01 & 181 & .181 & .359 \\
\hline $\begin{array}{l}\text { I provide earning's guidance and } \\
\text { current financial results (ST) }\end{array}$ & 7.61 & 3.20 & 182 & .180 & .358 \\
\hline $\begin{array}{l}\text { I keep up with the current stock price } \\
\text { and volume fluctuations (ST) }\end{array}$ & 8.93 & 1.84 & 181 & .181 & .359 \\
\hline Timeframe scale (LT - ST) & $1.04 \mathrm{LT}$ & 4.11 & 181 & .181 & .359 \\
\hline Cronbach's $\alpha$ for reliability & .70 & & 181 & & \\
\hline
\end{tabular}

Source: Elaborated by the author.

Figure 12. Timeframe scale

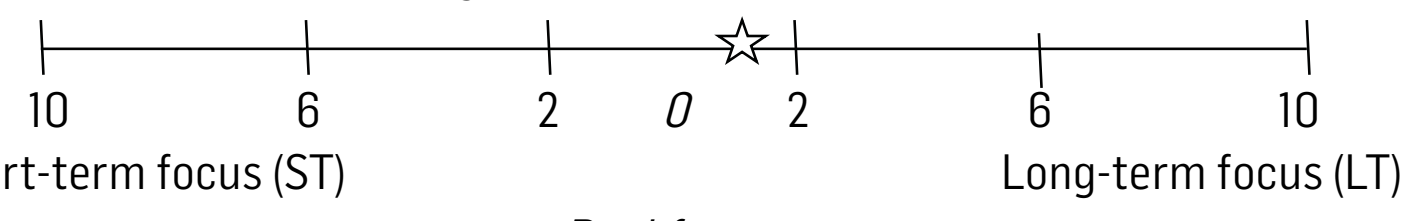

Dual focus

Source: Elaborated by the author.

Research Question 1 (Revised): Description of investor relations practice using scales of public relations

Combining data from all five scales helps us better answer Research Question1 about the general description of investor relations. Placed together in Table 7 and graphically in Figure 13, they create a visual display of the investor relations practice. 
Table 7. Mean scores of scales of public relations

\begin{tabular}{|c|c|c|c|c|c|}
\hline Activities & $M$ & $\sigma$ & $N$ & SES & SEK \\
\hline Direction of Communication Continuum & $.59 \mathrm{FC}$ & 2.82 & 181 & .181 & .359 \\
\hline Intended Beneficiary Continuum & $.68 \mathrm{BM}$ & 4.59 & 182 & .180 & .358 \\
\hline Enacted Role Continuum & .00 & 4.73 & 182 & .180 & .358 \\
\hline Nature of Investor Relations Continuum & $3.98 \mathrm{RA}$ & 4.19 & 181 & .181 & .359 \\
\hline Focus of Investor Relations Continuum & $1.04 \mathrm{LT}$ & 4.11 & 181 & .181 & .359 \\
\hline
\end{tabular}

Source: Elaborated by the author.

Figure 13. Scales of public relations: description of the investor relations practice
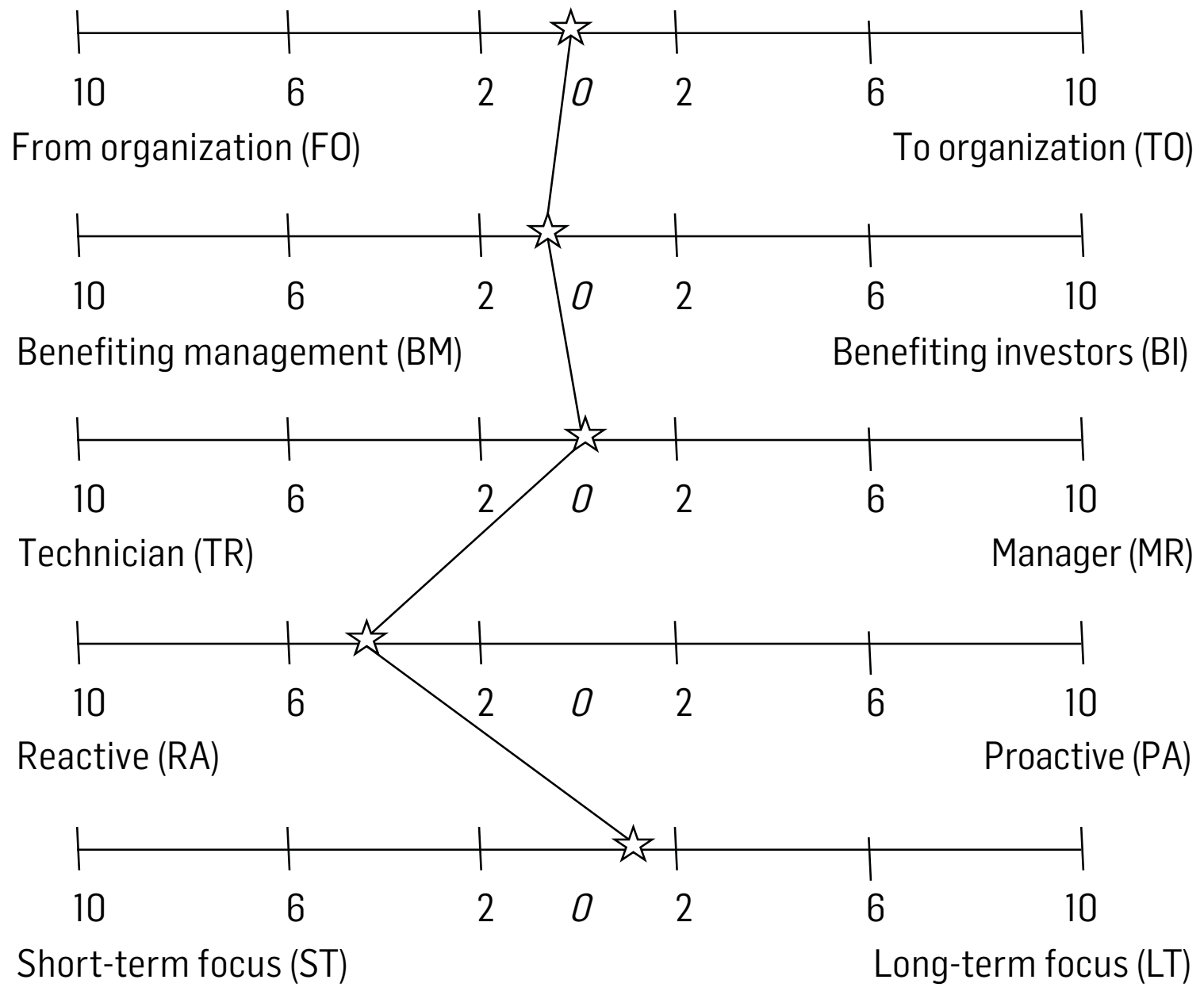

Source: Elaborated by the author.

The analysis results of the Scales of Public Relations indicate that investor relations work is characterized by two-way communication and balanced (symmetrical) effects. Although the job is mostly reactive in nature, investor relations professionals exercise both managerial and technical roles and focus on both short- and long-term objectives when carrying out their responsibilities. This can serve as a general description of investor relations as a PR specialization.

In addition, we conducted a cluster analysis based on the respondents' answers to the Scales of Public Relations, which allowed us to combine the participants into groups based on how they practice investor relations, thus achieving internal homogeneity in each cluster and external heterogeneity. This helped us, first, to understand what aspects of investor relations practice distinguish professionals from each other, and second, to assess the relationships between other variables that perhaps lead investor relations officers to perform their roles in one way or another. 
Results show that IROs can be divided into two clusters based on two main characteristics: the professional role that IROs play in their respective organizations $(F=182.19 ; p \leq .001)$ and the intended beneficiary of their work $(F=39.87 ; p \leq .001)$ (Table 8).

Table 8. Cluster analysis results for the scales of public relations

\begin{tabular}{|c|c|c|c|c|c|c|c|c|}
\hline & \multicolumn{2}{|c|}{ Cluster Centers } & \multicolumn{2}{|c|}{ Cluster } & \multicolumn{2}{|c|}{ Error } & $F$ & $P$ \\
\hline & Cluster 1 & Cluster 2 & MS & $d f$ & MS & $d f$ & & \\
\hline Direction & -.85 & -.57 & 1.83 & 1 & 8.03 & 176 & .23 & .634 \\
\hline Beneficiary & -5.33 & -.01 & 649.89 & 1 & 16.30 & 176 & $39.87^{*}$ & .000 \\
\hline Role & -7.81 & -1.34 & 1921.47 & 1 & 10.55 & 176 & $182.19^{*}$ & .000 \\
\hline Nature & -2.70 & -4.23 & 53.02 & 1 & 17.57 & 176 & 3.02 & .084 \\
\hline Focus & 1.11 & 1.06 & .06 & 1 & 17.02 & 176 & .00 & .952 \\
\hline
\end{tabular}

Source: Elaborated by the author.

Figure 14. Differences between two types of investor relations officers: managers and technicians.

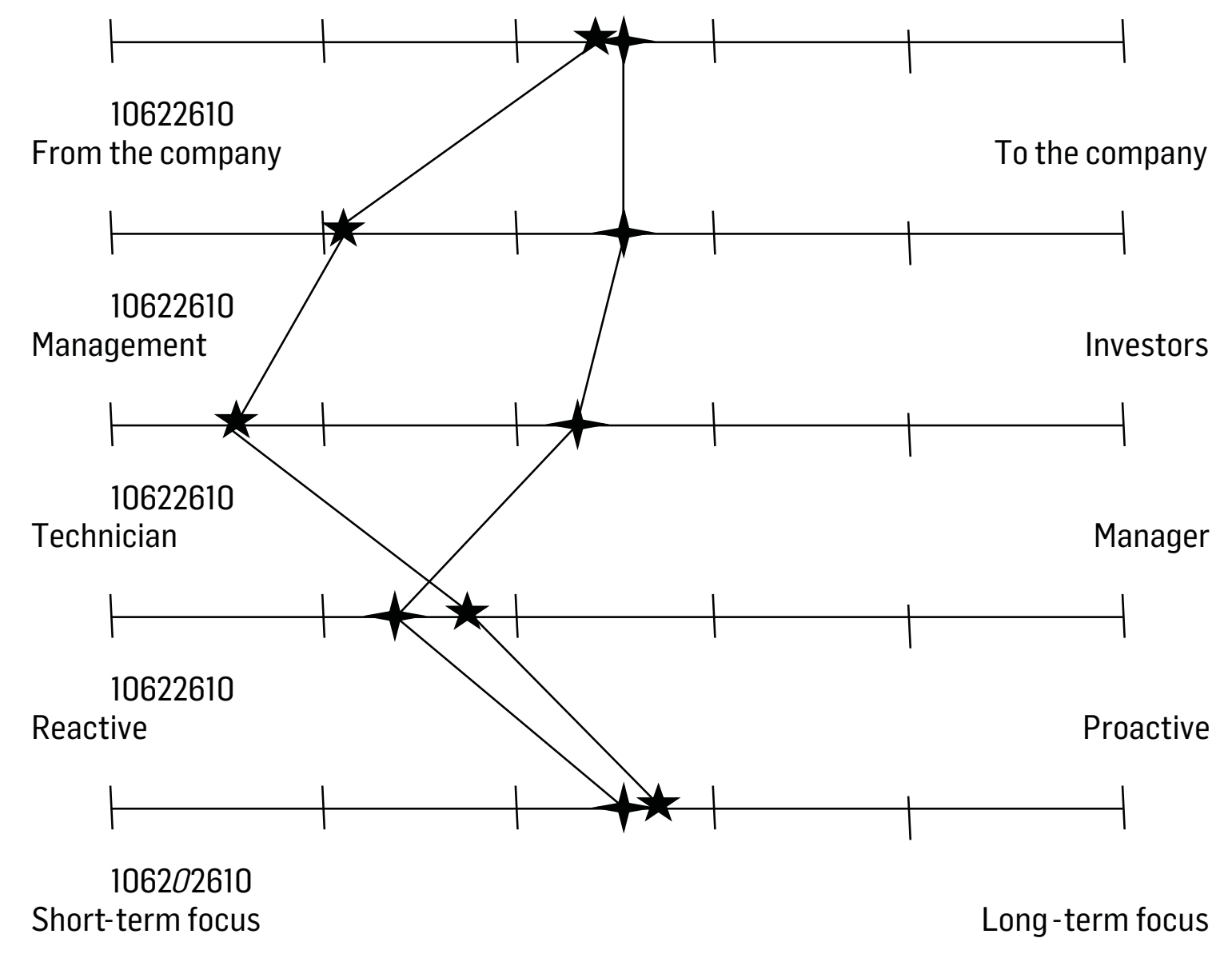

Source: Elaborated by the author.

The comparison between the two clusters of investor relations officers can also be plotted graphically (Figure 14), creating a visual display. Although all IROs showed to be more involved in technical than managerial tasks, cluster 1 was much more likely to perform technician tasks $(M=-7.81)$ than cluster $2(M=-1.34)$. Thus, we labeled cluster 1 as Technicians and cluster 2 as Managers. Members of the Managers group were more likely to practice investor relations as to contribute equally to benefit both the company's management and the shareholders $(M=-.01)$. Members of the Technicians group, in turn, perceived their investor relations work as primarily benefiting their company's management $(M=-5.33)$. The results of the other scales were similar for both groups: they facilitate two-way information flow (organization-public and public-organization), rely mostly on reactive rather than proactive strategies, and are equally focused on long- and short-term objectives. 
To provide external validation for cluster membership, we analyzed the titles of the investor relations officers in each cluster or their years of professional experience, assuming that senior IROs would be more likely to perform managerial tasks and see their work in a larger scope as benefiting not only the company, but also the shareholders.

The cross-tabulation results between IROs' titles and their cluster membership proved to be statistically significant $\left(\chi^{2}(4)=26.43\right.$; $p \leq .001$ ), thus supporting the assumption: respondents with senior titles, such as CEO/CFO and vice presidents, were more likely to be found in the second cluster, managers; while the first cluster, technicians, consisted mainly of respondents with lower ranks, such as managers and directors. Years of experience also corroborated cluster membership: respondents in the managers cluster had on average 3.16 years more experience in investor relations $(M=10.64)$ than respondents in the technicians cluster $(M=7.48)$. This difference was also statistically significant $(t=2.54 ; p \leq .05)$.

\section{CONCLUSIONS}

This study analyzed the professional practice of one of PR specializations - investor relations - testing a new methodological approach for measuring and evaluating public relations practice: the Scales of Public Relations.

Once measured together, these scales present a comprehensive picture of PR practice, which can be applied to measure such practice at different levels. The authors of the original models/dimensions of public relations, for example, explain that the Excellence project used the models three times to measure three different aspects of public relations practice: first, they measured "the worldview of the dominant coalition toward public relations" (Grunig et al., 2002, p. 331); second, "the models used for specific communication programs" (p.331-332); and third, "the knowledge needed for the two-way symmetrical model" (p.331). Importantly, the Excellence study concluded that the knowledge measurement showed higher reliability and higher means than the other two measurements. The Excellence study also measured the practitioner's roles three times: "Departmental expertise or knowledge to enact various roles, the actual roles enacted by each department's top communicator, and the role expectations of the organization's CEO" (Grunig et al., 2002, p.196).

Following the Excellence study's approach of measuring models/dimensions and roles multiple times and at various level, measurement of the proposed Scales of Public Relations can also be done at the individual, campaign, program, department, or organizational level, depending on the needs of the research. In the case of investor relations, for example, one can measure IR department, IR leader, individual IROs, specific IR campaigns, and the CEO's expectations of the IR function. Measurement can focus on the knowledge and expertise of professionals, as well as on actual daily activities, or on specific programs and campaigns.

Each of these measurement levels, of course, presents a different PR picture. As in the Excellence study, it might be more beneficial to combine several measurements from different levels to evaluate public relations practice. For example, the measurement results of a specific public relations program may be better explained by measuring the expertise of public relations professionals or by the expectation of the organization's dominant coalition.

The Scales can also be expanded to the public relations profession in general, and used to compare various public relations professional specializations with minor modifications to the wording of the questions. Investor relations measured in this study can be compared with community relations, for example, or environmental communications can be compared with health communications. The Scales also allow us to contrast public relations practices internationally. Comparing the professional practices, professional expertise, and expectations of public relations in different countries or regions of the world can be as simple as plotting them on the Scales and visually analyzing the differences. 
When applied to investor relations, the Scales showed that investor relations practice is best described as using two-way communications, having both management's and shareholders' interests in mind, focusing simultaneously on shortand long-term objectives, and performing both managerial and technical tasks. According to the results of this study, however, $\mathrm{IR}$ practice is more reactive than proactive.

When thinking about their work, IROs describe their most common activity as explaining. Of the 20 items measuring investor relations practice, "I explain my company to the investment community" ranked higher than any other item. As Laskin (2011; 2018) suggests, investor relations practice has undergone a shift from just providing information about the company to explaining the company's business model. Its purpose becomes to create understanding and manage expectations, not just disclosing numbers.

To be successful, investor relations today must be research-based, strategic and proactive. IROs in this study, however, do not rely on research and proactive activities in their work; rather, professionals passively respond to the issues as they arise. The second most highly rated item was "I answer requests from shareholders/investors, analysts, media, or senior management." One of the items measuring the proactive nature of investor relations, "I rely on planning and diagnosing needs/opportunities to do my work," had the lowest rating among all investor relations activity items.

It is unclear why the investor relations practice of corporations is predominately reactive. Too many responsibilities and lack of resources may perhaps limit IROs to just coping with the routine. Stround (2008) suggests that investor relations professionals "have less time and resources but more responsibilities" (p.2). The lack of proactive investor relations can also be explained by the absence of the necessary skills to develop proactive communication and conduct research. Most investor relations professionals lack strategic communication experience (Laskin, 2014; 2018), a reality that puts investor relations at risk. Higgins (2000) explains that proactive strategic investor relations is a necessity for a company to build "a link between the company and the investment community, responding to the needs of both" (p.26). Without research, IROs lack influence in management circles and may struggle to grow into a key shareholder value management role.

Another finding was the two-way symmetrical investor relations practice. In fact, Grunig et al. (2002) notes that investor relations may be one of the functions that require symmetry and two-way communications due to the power shareholders can exert over the company. As for the role and focus of investor relation activities, professionals seem to take on both technical and managerial roles and focus on both short- and long-term objectives. This perhaps indicates the shift from merely disclosing quarterly results to educating the stock market on long-term corporate value (Kelly et al., 2010; Laskin, 2018).

The study also found that IROs could be grouped into two clusters - managers and technicians - who practiced investor relations differently from each other: technicians served only to satisfy the company's management and performed predominately technical roles. However, even the technicians paid equal attention to short- and long-term objectives and two-way communication. Both groups exhibited a lack of proactive actions in their investor relations practice. Cluster analysis also served as a validity test of the Scales of Public Relations. Cluster membership was validated by external factors such as years of experience and professionals' title.

While this study was a successful empirical validation of the Scales of Public Relations, future research should test the Scales in other PR specializations and in various contexts. The instrument can be used to measure media relations, fundraising, public affairs, community relations, government relations, employee relations, etc. Its contribution to the body of knowledge lies in reconceptualizing and advancing previous research on models/dimensions of public relations and, as a result, adding to public relations theory and methodology. Future studies can expand the theory in investor relations and public relationsother scales, besides the five tested here, can be added to the instrument. The Scales can also be used to measure public 
relations practices in other countries and over time. Repeated applications of the instrument in various contexts will provide opportunities to further assess its validity and reliability.

\section{REFERENCES}

BOTAN, Carl; HAZLETON, Vincent. Public relations in a new age. In: BOTAN, Carl; HAZLETON, Vincent (ed.). Public relations theory Il. Mahwah: Lawrence Erlbaum Associates, p.1-18, 2006.

BROOM, Glen; DOZIER, David. Advancement for public relations role models. Public relations review, Knoxville, v.12, n.1, p.37-56, 1986.

BROOM, Glen; CASEY, Shawna; RITCHEY, James. Toward a concept and theory of organization-public relationships. Journal of public relations research, Abingdon, v.9, n.2, p.83-98, 1997.

CREEDON, Pamela. Acknowledging the infrasystem: a critical feminist analysis of systems theory. Public relations review, Knoxville, n.19, p.157-166, 1993.

DOVER, C. J. The shearing of the lambs: an irrelevant look at Excellence. Journal of management advocacy communication, Naples, v.1, n.1, p.38-44, 1995.

DOZIER, David. The organizational roles of communications and public relations practitioners. In: GRUNIG, James (ed.). Excellence in public relations and communication management. Hillsdale: Lawrence Erlbaum Associates, 1992, p.327-355.

DOZIER, David; BROOM, Glen. Evolution of the manager role in public relations practice. Journal of public relations research, Abingdon, v.7, n.1, p.3-26, 1995.

DOZIER, David; BROOM, Glen. The centrality of practitioner roles to public relations theory. In: BOTAN, Carl; HAZLETON, Vincent (ed.). Public relations theory II. Mahwah: Lawrence Erlbaum Associates, 2006, p.1-18.

DOZIER, David; GRUNIG, Larissa; GRUNIG, James. Manager's guide to excellence in public relations and communication management. Mahwah: Lawrence Erlbaum Associates, 1995.

FERGUSON, Mary Ann. Building theory in public relations: interorganizational relationships. In: ANNUAL CONVENTION OF THE ASSOCIATION FOR EDUCATION IN JOURNALISM AND MASS COMMUNICATION, 67., 1984, Gainesville. Proceedings [...]. Gainesville: AEJMC, 1984.

GRUNIG, James. Organization and publics relations: testing a communication theory. Journalism monographs, Austin, V. $46,1976$.

GRUNIG, James. Organizations, environments, and models of public relations. Public relations research \& education, Corvallis, v.1, n1, p.6-29, 1984.

GRUNIG, James; GRUNIG, Larissa. Modes of public relations and communications. In: GRUNIG, J. (ed.), Excellence in public relations and communication management. Hillsdale: Lawrence Erlbaum Associates, 1992.p.285-325. 
GRUNIG, James; HUNT, Todd. Managing public relations. New York: Holt, Rinehart and Winston, 1984.

GRUNIG, Larissa; GRUNIG, James; DOZIER, David. Excellent public relations and effective organizations. Mahwah: Erlbaum, 2002.

HEATH, Robert; COOMBS, William Timothy. Today's public relations: an introduction. Thousand Oaks: Sage, 2006.

HON, Linda Childers; GRUNIG, James. Guidelines formeasuring relationships in public relations. Gainesville: The institute for public relations, 1999. Disponível em: https://www.instituteforpr.org/wp-content/uploads/Guidelines_Measuring_Relationships.pdf. Acesso em: 4 jun. 2021.

HUANG, Yi-Hui. PRSA: Scale development for exploring the cross-cultural impetus of public relations strategies. Journalism and mass communication quarterly, Thousand Oaks, v.81, n2, p.292-307, 2004.

KELLY, Kathleen; LASKIN, Alexander; ROSENSTEIN, Gregory. Investor relations: two-way symmetrical practice. Journal of public relations research, Abingdon, v.22, n.2, p.182-208, 2010.

KUNCZIK, Michael. Public relations: Angewandte Kommunikationswissenschaft oder ideologie? Ein Beitrag zur ethic der offentlichkeitsarbeit [Public relations: applied communication science or ideology? A contribution to the ethics of public relations]. In: ARMBRECHT, Wolfgang; ZABEL, Ulf (ed.). Normative aspects der public relations. Leverkusen: Westdeutscher Verlag, 1994, p.225-264.

LASKIN, Alexander. The evolution of models of public relations: an outsider's perspective. Journal of Communication Management, Bingley, v.1 3, n.1, p.37-54, 2009.

LASKIN, Alexander. How investor relations contributes to the corporate bottom line. Journal of Public Relations Research, Abingdon, v.23, n3, p.302-324, 2011.

LASKIN, Alexander. Public relations scales: advancing the excellence theory. Journal of communication management, Bingley, v.16, n4, p.355-370, 2012.

LASKIN, Alexander. Investor relations as a public relations function: a state of the profession in the United States. Journal of public relations research, Abingdon, v.26, n.3, p.200-214, 2014.

LASKIN, Alexander. Nonfinancial information in investor communications. International journal of business communication, Thousand Oaks, v.53, n.4, p.375-397, 2016.

LASKIN, Alexander. Investor relations and financial communication: the evolution of the profession. In: LASKIN, Alexander (ed.). Handbook of financial communication and investor relations. Walden, MA: Wiley-Blackwell, 2018, p.3-22.

LEDINGHAM, John. Explicating relationship management as a general theory of public relations. Journal of public relations research, Abingdon, v.15, n.2, p.181-198, 2003.

LEICHTY, Greg; SPRINGSTON, Jeff. Reconsidering public relations models. Public relations review, Knoxville, v.19, n.4, p.327-339, 1993. 
LEITCH, Shirley; NEILSON, David. Bringing public into public relations: new theoretical frameworks for practice. In: HEATH, Robert (ed.). Handbook of public relations. Thousand Oaks: Sage, 2001, p.127-138.

L'ETANG, Jacquie. Clio among the patriarchs: historical and social scientific approaches to public relations: A methodological critique. INTERNATIONAL PUBLIC RELATIONS SYMPOSIUM, 2., 1995, Bled. Proceedings [...]. Bled: BledCom, 1995.

LYOTARD, Jean-François. Answering the question: what is postmodernism? In: JENCKS, Charles (ed.). The postmodern reader. London: Academy, 1992, p.138-150.

MURPHY, Priscilla. Game theory as a paradigm for the public relations process. In: BOTAN, Carl; HAZLETON, Vincent. (ed.). Public Relations Theory. Hillsdale: Erlbaum, 1989.p.173-192.

MURPHY, Priscilla. The limits of symmetry: a game theory approach to symmetric and asymmetrical public relations. Public relations research annual, Abingdon, v.3, p.115-131, 1991.

PIECZKA, Magda. Symmetry in communication and public relations. In: SECOND INTERNATIONAL PUBLIC RELATIONS SYMPOSIUM, 1995, Bled, Slovenia. Anais [...]. Bled: 1995.

PIECZKA, Magda. Paradigms, systems theory and public relations. In: L'ETANG, Jacquie; PIECZKA, Magda (ed.). Critical perspectives in public relations. London: International Thomson Business Press, 1996, p.124-156.

ROPER, Juliet. Symmetrical communication: excellent public relations or a strategy for hegemony? Journal of public relations research, Abingdon, v.17, n.1, p.69-86, 2005.

SHA, Bey Ling. (2007). Dimensions of public relations: moving beyond traditional public relations models. In: DUHÉ, Sandra (ed.), New media and public relations. New York: Peter Lang, 2007, p.3-26.

WIMMER, Roger; DOMINICK, Joseph. Mass media research: an introduction. 7. ed. Belmon: Thomson Wadsworth, 2003.

Article received on 05.04.2021 and approved on 18.05.2021 